\title{
コイルば放の疲労変形*
}

\author{
山田撖**吉田忠俊***
}

\section{Fatigue Deformation of Coiled Spring}

by

\author{
Iwao YAMADA and Tadatoshi YosHIDA \\ (Himeji Technical College)
}

Coiled springs are used in many kinds of automatic or semi-automatic product machines.

If the fatigue deformation takes place in these springs, even if fatigue failure may not occur, the capacity and the accuracy of these machines may be affected adversely. Investigations on the fatigue deformation of the coiled spring have not deen conducted extensively so far.

In this report the fatigue deformation limit diagram is studied experimentally on the three kinds of the coiled spring of steel wire, that is untreated, heated and setting. The results obtained are as follows :

(1) The effect of secular change on the fatigue defomation of coiled spring is negligiby small but the effct of elastic-after effect can not be neglected on the untreated coiled spring. Therefore, the fatigue deformation is necessary to be measured as soon as possible after unloading.

(2) The fatigue deformatiom limit of the untreated coiled spring is the lowest, but by heating these, the limit increases remarkably. It seemes that such an increase of the fatigue deformation limit by heating is mainly due to age-hardening.

(3) The fatigue deformation limit diagram of the coiled spring used in this experiment is curved above the staight line of 45 degrees with the axis of abscissa (mean stress axis).

(Received May 30, 1962)

\section{1. 緒言}

近来各種の自動あるいは半自動生産機械や自動制御 機器が用いられるようになってきたが，これらに用い られている作動ばねでは，たとえ疲労破壞は起こらな くても疲労変形が起こると, それが機械や装置全体の 機能, 精度に悪影響を及仿す場合がしばしば見受けら れる。しかしコイルばねの疲労変形やその防止に関す る研究は, 河本らによる一連の研觉があるほかはあま り見受故られないように思われる。同氏らの報告によ ると, 静的に平均荷重のみ加えた場合（圧縮クリープ 变形限度)上り繰返圧縮荷重を加えた場合 (压繀疲労变 形限度)のほうがむしろ変形の起こりにくい $\tau_{a} / \tau_{m}$ の 領域が存在することを示している。

このような傾向は従来棒材についてあまり認められ ない結果である。これが材料のいかんにかかわらず起 こる現象であるかいなかを調へ，その原因を明らかに する意味でももう少しデーターの蓄積が必要であるよ゙

\footnotetext{
* 原稿受付 昭和 37 年 5 月 30 日, 当協会第 10 期総会講演会にて講 演 (昭36.5)

*** 正員 姫路工業大学

**** 山陽特殊製鋼 (侏)
}

うに思われる。ょたコイルばねの疲労変形限度を定 めるためには, 比較的小さな変形を問題とする関係上, コイルばねの弾性余効果や製造後の経年変形がコイル ばねの疲労変形の測定值に影響するかいなかを明らか にしておく必要があるように思われる。

本報は上述の意味から，自動ばね巻機で巻いたまま の無処理ばね,これにブルーイングを施したばね,さ らにセッチングを施したばねの 3 種のコイルばねにつ いてまず，弾岯余効果および経年变形の大きさを調べ て, 疲労変形の測定值に及ぼすそれらの影響を検討す るとともに, 疲労变形限度線図を求め, ブルーイング およびセッチングの効果について考察したものである.

\section{2. 試験ばねおよび試験方法}

本実験に用いたコイルばねの素線は Table 1 に示

Table 1 Chemical composition of wire for coiled spring (\%)

\begin{tabular}{c|c|c|c|c|c|c|c}
\hline $\mathrm{C}$ & $\mathrm{Si}$ & $\mathrm{Mn}$ & $\mathrm{P}$ & $\mathrm{S}$ & $\mathrm{Cu}$ & $\mathrm{Ni}$ & $\mathrm{Cr}$ \\
\hline 0.82 & 0.48 & 0.22 & 0.013 & 0.013 & 0.01 & - & 0.02 \\
\hline
\end{tabular}


すような化学成分の硬引鋼線で，直径 $7 \mathrm{~mm}$ 加ら数回 引き拢いて $5.5 \mathrm{~mm}$ 直堡とし，ここでパテンチング処 理を施してから再び数回引き拔いて $3 \mathrm{~mm}$ としたもの である。このような素線から自動ばね巻機で巻いた二 イルばねの寸法は自由長 $46 \mathrm{~mm}$, 平均直㿻 $20 \mathrm{~mm}$ 有 効巻数 8.25 である。試駼ばねとしてはコイル巻きの ままの無处理ばね(Cばねと呼ぶことにする)，これを $350^{\circ} \mathrm{C}$ で15分間ブルーイングしたばね（Bばね），さ らにこれを密着灾力まで 3 回セッチングしたばね（S ばね)の 3 種を選んだ。

疲学変形の湘定は $\tau_{a} / \tau_{m}=0,0.25,0.50,0.83$ の 各場合について行なった. $\tau_{a} / \tau_{m}=0$ の尖験を行なう ための試験機は重鍾を用いて試験ばねに一定の荷重が

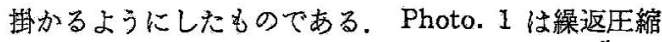
荷重を加えるために造ったュイルばね疲学試験機であ る. 二重偏心力ムCの回転 $(920 \mathrm{rpm})$ によってこれと 接触するローラーRを介して押し棒を上下させて，応 力振幅に相当するたわみ(偏心量 $=\delta_{a}$ )を訊験ばねに与 える.

二重偏心カム C を形成する外側のローラーはラジ ルボールベアリングを前い，これに接触するローラー にも同様のベアリングが用いてある．また，二重偏心 カムの下部はオイルバスの中に浸し，試験ばねSおよ び従動ローラーを強制接触させるば放ざな゙の接触

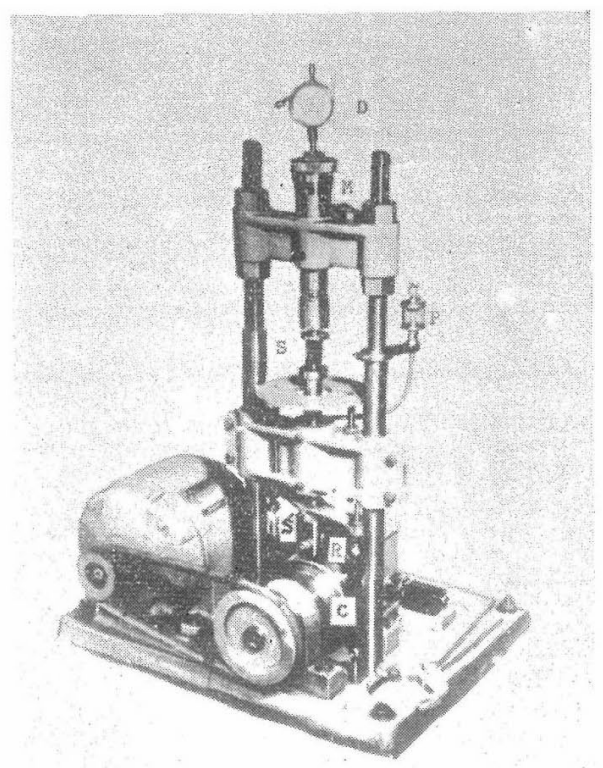

Photo. 1 Fatigue testing machine for coiled spring

S: Coiled spring (test piece),

$M$ : Micrometer head $\mathrm{C}$ : Cam,

$\mathrm{R}$ : Roller, $\mathrm{S}^{\prime}$ : Tension spring

P: Oil cup
正力に基づく発熱および摩耗を減少させるようにした， 試験ばねSの受座には静荷重用, 動荷重用試駼機とも スラストボールベフリングを用いたが，これは塑性た わみの発生に伴うコイルばね端面の角变位を自由にす るためである。

ダイヤルゲージ あることを確かめてから，マイタロメーターへッドM （最小目盛0.01 mm）を送ってあらかじめコイルばね を圧維しておく（王縮荷重を $P_{m}$ とし，压縮たわみを $\delta_{m}$ とする).このとさの偏心量を $\delta_{a}$ (これに相当する 殴縮荷重を $P_{a}$ とする）とすると，試験機を運伝する

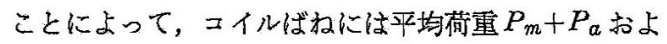
び荷重恸幅 $P_{a}$ が作用することになる.

一般に圧縮コイルばねの応力およびたわみには，ね

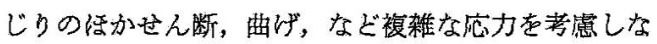
ければならないが,これらのうちねじりの影響が最も 大きいと考えられるから，コイルば权を縮した場合 の応力振幅を $\tau_{a}$, 平均応力を $\tau_{m}$ とすれば

$$
\frac{\tau_{a}}{\tau_{m}}=i=\frac{P_{a}}{P_{m}+P_{a}}=\frac{\delta_{a}}{\delta_{m}+\delta_{a}}
$$

また，王縮街重 $P$ とばね菜線に掛かるねじり応力 との間には次式の関係がある。

$$
P=\frac{\pi d^{3}}{8 D} \cdot \tau
$$

ここにdは素線の直惩，Dはコイルの平均直径である。 かりにば放定数 $K$ 疲学試験の前後で変わらないも のとすれ举，応力綝返し中に試験ばねに疲労变形が生 ずると， $\delta_{m}$ の值が滅少することになり，(1)式の $i$ の值が変わってくるから，マイクロターターッドを回 転して，生じた疲学变形量だけさらにコイルばねを压 繀する必要がある。

なお，たわみ量 $\delta$ からせん断ひずみ $\gamma$ を求めるのに は

$$
r=\frac{\tau}{G}=\frac{16 P R}{\pi d^{8}} \frac{1}{G}=\frac{8 P D}{\pi d^{3}} \frac{\delta d^{4}}{8 P D^{3} n}=\frac{d}{n \pi D^{2}} \delta
$$

を用いた。

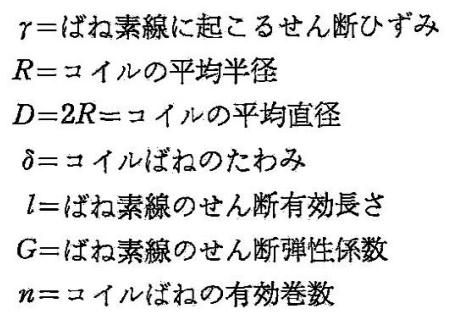

コイルばねの变形量はコイルばねの自由長の变化と して求められるから，静荷重のとさは所定時間ごとに，

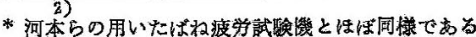

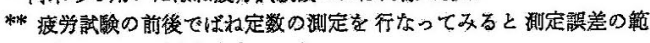
缃内てはとんど变わらなかっだ 
繰返荷重のときは所定回転数ごとに試験機からはずし

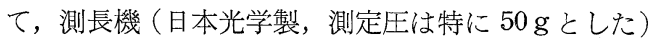
によって端面円周 8 等分した各個所について自由長を 測定し平均值を求めた。

\section{3 . 実 験 結 果}

\section{（Ｉ）コイルばねの弾性余効果および経年変形}

弾情余効果が存在すれば，除荷後いつ測定を行なう かによって変形量が異なることになり, 経年变形が存 在すれば，ばねを製作後測定する時期によって各個の ばねに寸法变化が起こり, 厳密な実験結果の整理がむ ずかしくなる。また，試験中にも経年変形が起これば， ばねの変形量は真実の疲学变形量より大さめあるいは 小さめに測定されることになり，これらの存在は変形 の測定誤差の原因となる。したがって，弾些余効果お よび経年变形によるコイルばねの寸法变化がどの程度 のものであるかを調べておくことは重要なことである。

Fig. 1 はCばねおよびBばねに $20.6 \mathrm{~kg}$ (せん断応 力 $\left.\tau=38 \cdot 7 \mathrm{~kg} \cdot \mathrm{mm}^{2}\right)$ の圧縮荷重を 10 時間負荷した場 合と，Cばねに $24 \cdot 8 \mathrm{~kg}\left(\tau=46 \cdot 5 \mathrm{~kg} / \mathrm{mm}^{2}\right)$, B吕ね に $29.3 \mathrm{~kg}\left(\tau=55 \cdot 0 \mathrm{~kg} / \mathrm{mm}^{2}\right)$ の圧縮荷重を瞬間的に 加えて除荷した場合の時間の経過に伴う变形の回復状 沉を示したものである.いずれも寸法変化は最小目盛 $1 \mu$ のダイヤルゲージで測定した.

同図から明らかなように，初め变形の回復が著しい が，しだいに回復速度を減じ，本実験の精度では約 2 時間程度経過するとほぼ一定となる。Cばねの場合 $\tau=38.7 \mathrm{~kg} / \mathrm{mm}^{2}$ の静応力を 10 時間負荷すると, 後 述する Fig. 4 や Fig. 5 からも想像されるように約 $0.4 \mathrm{~mm}$ の塑愔変形が起こり, 変形の回復量も大きい (約 $96 \mu$ に及ぶ). $\tau=46.5 \mathrm{~kg} / \mathrm{mm}^{2}$ であっても，瞬間 的に作用させた場合には变形の回復量はわずか $14 \mu$ であった。しかし，ブルーイングしたBばねでは静荷 重を 10 時間負荷した場合で約 $12 \mu, 55 \cdot 0 \mathrm{~kg} / \mathrm{mm}^{2}$ を 瞬間的に作用した場合で $1 \mu$ 程度であった。これらの 結果から弾性余効果の影響は荷重の種類や材質によっ

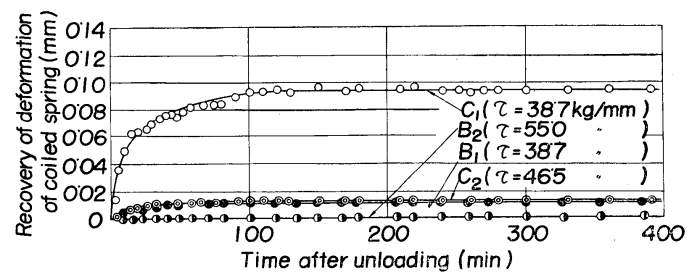

Fig. 1 Recovery of deformation of coiled spring by elastic after-effect

$\mathrm{C}_{1}$ : Untreated spring (Unloaded after loading at 10h)

$\mathrm{C}_{2}$ : Untreated spring (Unloaded after instantaneous loading)

$\mathrm{B}_{1}$ : Heated spring (Unloaded after loading 10h)

$\mathrm{B}_{2}$ : Heated spring (Unloaded after instantaneous loading)
てかなり相違があることがわかる。

Fig. 1 から静荷重が長時間作用してかなりの塑性変 形が起こる場合には，弾性余効果の影響が大きいこと がわかったので，除荷してから測定するまでの経過時 間の影響を検討した。すなわち，Cばねについては $31 \cdot 1,36 \cdot 7,44 \cdot 6 \mathrm{~kg} / \mathrm{mm}^{2}$, Bばねについては $50 \cdot 1$ お よび $52 \cdot 0 \mathrm{~kg} / \mathrm{mm}^{2}, \mathrm{~S}$ ばねについては $45 \cdot 7,52 \cdot 8$ お よび $54.5 \mathrm{~kg} / \mathrm{mm}^{2}$ の各応力を静的に 5 時間 (一部に ついては 10 時間) 負荷し，各 5 時間 (一部は 10 時間) ごとに除荷して直ちに測定した場合と除荷してから 2 時間放置後に测定した場合の各コイルばねの变形量は Fig. 2 のとおりである.ただし，Fig. 2 は上述の結果 の一部を示したものである。 2 時間経過後の測定值 (点線)は弾临回復が大きいから，除荷後直ちに測定し た場合(実線)に比べて変形量が少ないが，実線と点線 とは全く同様の傾向で，両者の差はばねC を除けば比 較的小さな值であり，除荷後できるだけ短時間内に測 定すれば，これらの差はさらに軽减できることがわか る。

次に経年变形について調べた。自動ばね巻機で巻い てから 1 日経過したC グおよびセッチング処理を施してBばねやSばねを造 りこれら 3 種のばねについて常温に放置した時間の

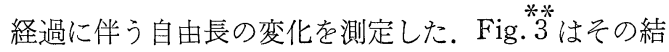
果を示したものである、Cばねでは製作後変形(縮み) が起こり，約 7 日間でほぼ一定になる。Bばねではブ ルーイングによって安定化しており，变形はほとんど 起こらない，Sばねもセッチング前のブルーイングに よって安定化しており, むしろセッチング後の弾性余 効果によってごくわずかの変形(伸び)が起こる．しか しこれらの変形はいずれもミクロンのオーダーで，こ

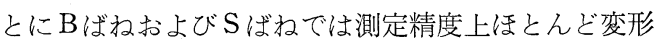
は起こらないといってよい程度である。

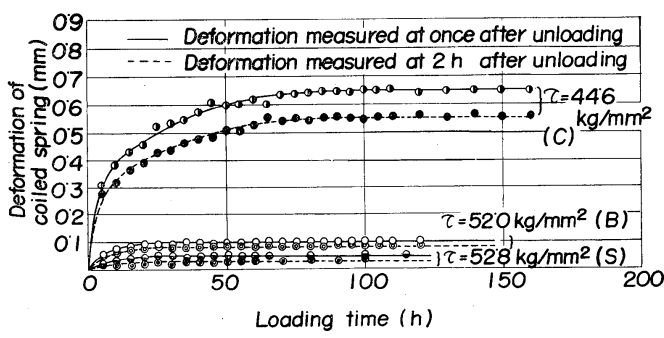

Fig. 2 Effect of time elasped after unloading on the deformation of coiled spring C: Untreated spring, B: Heated spring, $\mathrm{S}$ : Setting spring

* 弹性余効果による变形の回復が㭬倡完了する時間を選んだ

***ばね衫の製作後約 1 日経過した点を原点としているが，他はブ ルーイングあるいはセッチング処理直後を原点として表わしてあ る 
以上の結果から，Cばねの弾览余効果の場合を除け ば, 变形の測定誤差に及ぼす弾性余効果および経年変 形の影響はいずれも疲労変形を見かけ上增加させるよ うに作用し, 変形に対する安全応力を定める場合に安 全側にある。これらの理由から経年変形を無視し, 弾 性余効果の影響を考虑して，コイルばねの変形の測定 は除荷後 5 分以内に終了するようにした.

\section{（II） 静荷重によるコイルばねの変形}

Fig. 4 はCばね，Bばね，Sばねの各コイルばねに わいて, 静荷重を種々变えて变形量を測定した結果の 一部を示したものである。処理の種類にかかわらず, 負荷によるコイルばねの変形量は負荷の初めに著しく 進行し, しだいに增加割合を減じてついにそれ以上变 形は起こらなくなる。しかも同一ばねでは負荷応力が 大きいほど変形量が大きくなり，ほぼ同一の負荷に対 してSばね，Bばね，C㫗ねの順に変形が大きくなる ことがわかる。

この関係を明らかにするために, 負荷荷重から (2) および ( 3 )式によって求めたせん断応力と残留せん断 ひずみとの関係を示すと Fig. 5 のようになる. Fig. 5 から静荷重によるコイルばねの変形量は，Cばねが 最も大きく、これにブルーイング処理を施す（Bばね） と変形量は著しく減少し, さらにセッチングを施す Sばねと変形量が最も少なくなることがわかる.

\section{（III） 繰返荷重によるコイルばねの変形}

$\tau_{a} / \tau_{m}$ の值を前述の $0.25,0.5,0.83$ の 3 種類に変

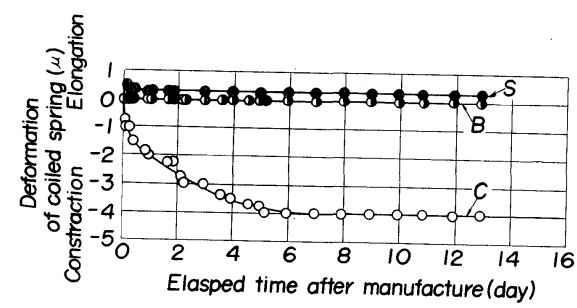

Fig. 3 Effect of secular change on the size of coiled spring

C: Untreated spring, B: Heated spring, $\mathrm{S}$ : Setting spring

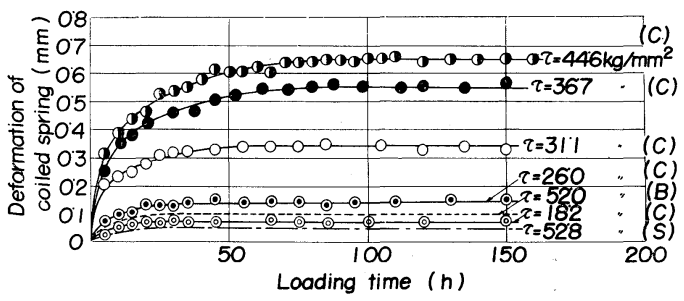

Fig. 4 Creep curves for coiled springs by static compression

C: Untreated spring, B: Heated spring, $\mathrm{S}$ : Setting spring
えて, 繰返压縮荷重を加えた場合にコイルばねの変形 がぞのように起こるかを調べた．Fig. 6 はBばねにつ いて得られた結果である(ただし $\tau_{a} / \tau_{m}=0.5$ の場合 のみ示してある)。同図からコイルばねの疲労变形は 繰り返しの初期に主として進行し, その後繰返数が增 すにつれてその増加がしだいにやみ，ついに全く変形 の進行が停止するようになり, 変形の增加傾向は静荷 重を負荷した場合と同様である.

各ばねについて得られた Fig. 6 のような結果に基 づいて，一定となった変形量を用いて $(3)$ 式からせん 断ひずみとを計算して横軸にとり, 緃軸に加えた最大 応力をとって表わすと Fig. 7 のようになる. Fig. 5， 7 から残留せん断ひずみ $\gamma=0.5 \times 10^{-5} \mathrm{rad}$. に相当す る応力 $\tau_{\max }$ から $\tau_{a}, \tau_{m}$ を求め, 疲労变形限度線図を かくと Fig. 8 のようになる。これらの結果からCば ねでは疲労変形限度がはなはだ低いが，これを $350^{\circ} \mathrm{C}$

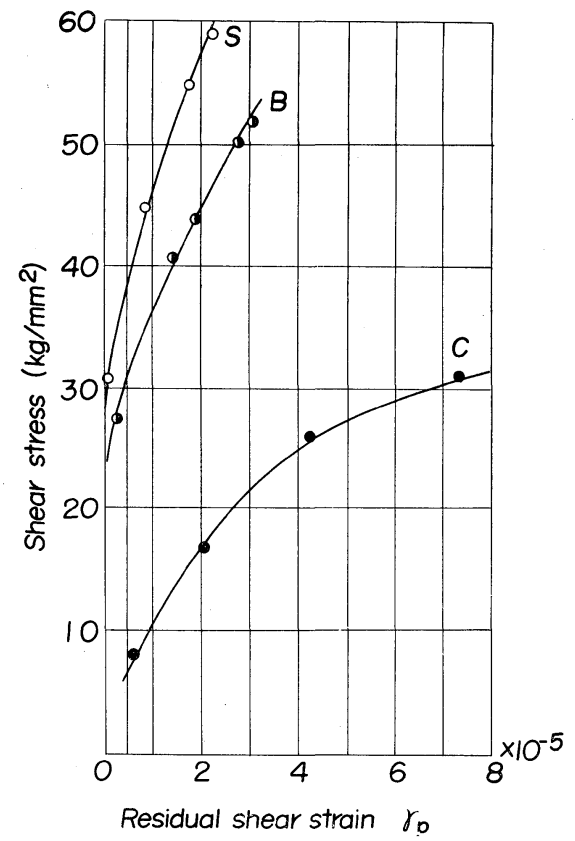

Fig. 5 Creep deformation of coild spring ${ }_{2}^{\text {sby }}$ stalic load

C: Untreated spring, B: Heated Spring S: Setting spring

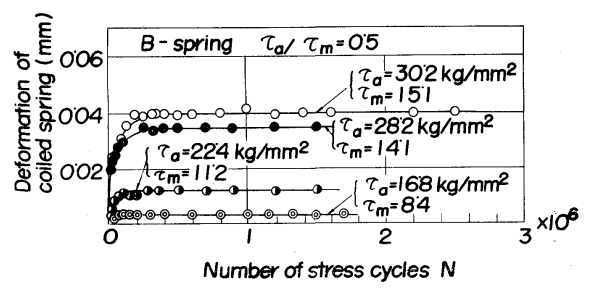

Fig. 6 Fatigue deformation of coiled spring by repeated load 
で 15 分間ブルーイングすることによって，疲労変形 限度が著しく上㫒し，これにセッチングを施すことに よってさらに上㫒することがわかる。またこれらの 線図の形はばねの処理のいかんにかかわらずほぼ同一 で，いずれも横軸と $45^{\circ}$ をなす直線に対して上万に凸 な弓形になっている。 そうして $\tau_{a} / \tau_{m}=0 \cdot 3 \sim 0.4$ 程 度のとき疲労变形限度が最大になる。この結果から計 算すると, $\tau_{m}=(0.25 \sim 0.33) \tau_{a}$ 程度の平均応力を与 えて使用する場合のほうが，むしろ疲労変形が起こり にくいことがわかる。

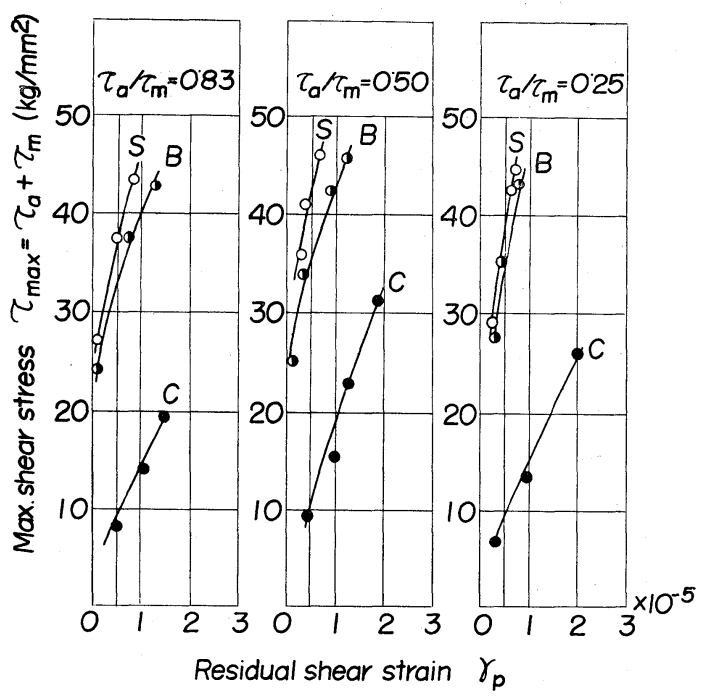

Fig. 7 Fatigue deformation of coild spring by repeated load

C: Untreated spring, B: Heated spring, $\mathrm{S}$ : Setting spring

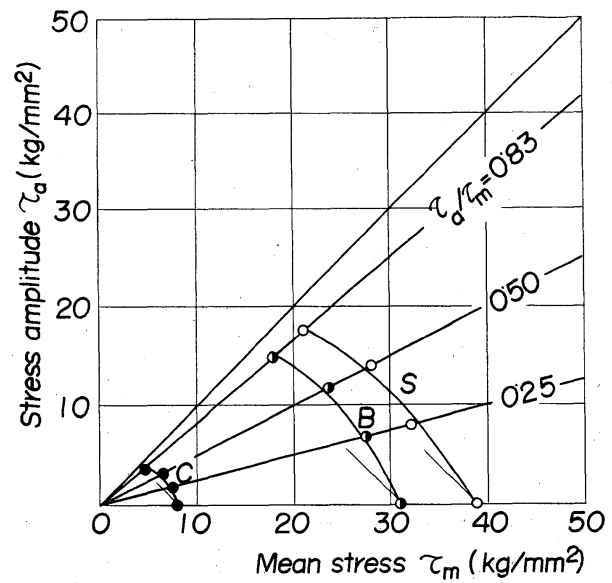

Fig. 8 Fatigue deformation limit diagram of coild spring

C: Untreated spring, B: Heated spring, $\mathrm{S}$ : Setting spring

\section{4. 考察}

経年変形は長期にわたる問題であるが, Fig. 3 の結 果をこれ以上大さく变えるとは考えられない，また， 疲労变形はコイルばねの各実験開始時の寸法を基準に しているので，製作してから以後の経年変形はほとん ど疲労变形の測定誤差とならない。むしろ繰返応力に よって経年変形が助長されることの影響や, 繰返応力 によって試験中ばねの温度が上㫒すると，材質，温度 の組み合わせによって種々複雑な变形が起こる心配が あるが，後者については本実験の範囲内で温度の上昇 はほとんど認められなかった，前者については繰返応 力による経年变形と疲労变形とを分離して測定するこ とができないので明確なことはいえないが，経年变形 が繰返応力によって特に增大するとは思われない、こ とに実用ばねはコイル巻さのままで使用されることは 絶無で, 必ずブルーイングやさらにセッチングが施さ れている。したがって，実用ばねでは経年变形の影響 は無視してよいだろうし，弾性余効果の影響も除荷後 5 分以内に变形の測定を終るようにすることによって かなり軽減できる。

次に，Fig. 8 からCばねをブルーイングすることに よって著しく疲労变形限度が上昇することがわかる。

ブルーイングによるこのような疲労变形限度の上㫒 は次の諸点に関係があると考えられる。

（1）コイルばねは製造工程において，かなり強度 の伸線加工と曲げ加工とわずかながらねじり加工を受 けているから, 複雑な残留応力を有すると考えられる が，ブルーイングによって残留応力が減少するであろ j.

（2）試験ばねは $0.82 \% \mathrm{C}$ 鋼線で，フェライトはご くわずかしか存在しないから程度は少ないと思われる が，ブルーイングによってひずみ時効硬化が起こるで あろう。

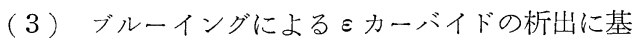
づく強化が起こるであろう。

このように考えると，もし $0.4 \sim 0.5 \% \mathrm{C}$ 鋼線をコ イルばねに使用し，ホットセッチング（ある温度のも とでセッチングする処理をこのように名づけておく） を行なえば，(ii).の影響が大きくなり，変形の防止に 有効なのではないかと推定されるが，この点に関して は最近河本らによって㬰証された。

次にセッチングは疲労变形の防止に対して, 果して 本質的に有効なのであろうかという点について考えて みる。

コイル巻きという一種の前加工を施したCばね材に 荷重を加えると，Fig. 9 ( a )のC曲線のような $\tau-\gamma$ 線 図をかくものとし，Cばねにブルーイングを施してB ばねを造ると，前述のブルーイングの効果でBばね材 
の flow stress はかなり上䄯し，B曲線のようになる とする。これにセッチングを施してSばねを造った場 合, セッチングによって本実験の場合約 $0 \cdot 1 \mathrm{~mm}$ (せ ん断ひずみにして約 $\left.2 \cdot 9 \times 10^{-6}\right)$ のへた节を生ずるが, この程度の加工度では加工硬化に奇与するとは考えら れず，事実セッチングしたものの硬度はブルーイング したものの硬度 (340 DPN) と活とんど同じであった。 したがって,ブルーイングによってくぎづけされた転 位の一部は, 七ッチングによって解放される結果, む しろSばね材の flow stress は低下する傾向になり， 点線の $\mathrm{S}$ 曲線のようになるか， あるいは $\mathrm{B}$ 曲線とほと んど同じで， $\mathrm{S}$ 曲線のほうが $\mathrm{B}$ 曲線より高くなること は考えにくいように思われる。しかしながら Fig. 7 のBばね，S将ねにいて得られた結果は上述の傾向 と相違しているが，筆者はこれを見かけ上現われたも のと考える.

rの測定值に影響する因子として考えられるものの 一つにセッチングによるコイルばねの寸法変化（自由 長, コイル径, 有効巻数の変化) があるが, 本実験に 用いたばねの場合，自由長は約 $0.1 \mathrm{~mm}$ 滅少し，コイ ル径は約 $0.01 \mathrm{~mm}$ 増加しているが, 有効巻数 $n$ の変 化についてはその值をつかむことができないので，か りにnは変わらないものとし，(3)式からせッチング によるコイルばね寸法変化を考虑した場合と, 考慮し ない場合の $\gamma$ 差を求めると $\Delta \gamma=3 \times 10^{-7}$ となり, 考 慮する場合のほうが Fig. 7 のSばねの曲線を. $\Delta \gamma$ だ け綎軸に近い側(左側)に移動させることになるが、こ の程度の $\Delta \gamma$ は測定の誤差範囲にあるので問題はない． 他の因子としては Fig. 7 をかく際にセッチングに よる変形を疲労変形として取り报っていない点がある。 いまかりにBばね，S齐材の $\tau-\gamma$ 線図が活とんど同 一であるとする。同じ応力条件では両ばねとも $\gamma-N$

(a)

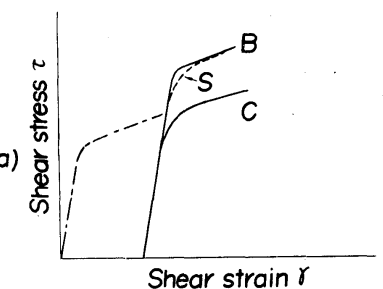

(b)

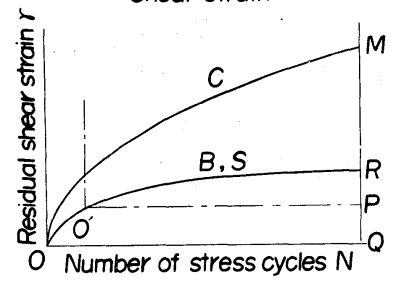

Fig. 9 Schematir stress-strain and fatigue deformation diagram $\mathrm{PQ}=$ deformation by setting
線図 (Fig. 9 (b )) が同一の曲線になるであろうが, $\gamma$ の測定に際し $S$ ばねのみセッチングによって生じ た変形量だけ原点を $\mathrm{O}^{\prime}$ 点にずらした形で測定されて いるために，Fig. 7 をかくときの rの值としてはBば ねでは Fig. 9 (b)の $R Q$ の値が $\mathrm{S}$ ばねでは $R P$ の值 が採用されているので，同じ程度の変形を生ずべき場 合でも，Bばねに比べSばねの変形は少なくとられて いる。したがって，本実験の場合では Fig. 7 のSば ねの曲線をセッチングによるへたり $0 \cdot 1 \mathrm{~mm}$ すなわち $\gamma=2 \cdot 9 \times 10^{-6}$ だけ右にずらせば，この点の大略の補正 がなされたことになり，このようにすれば S ばねの曲 線はBば水の曲線と接近し，Fig. 8 に現われているほ どセッチングによる疲労変形限度の上界は認められな くなり，製造工程からくる個々のコイルばねのばらつ きを考慮すれば，Bばね，Sばねの痏労变形限度はほ とんど变わらないのではないかと考えられる。

したがって，セッチングによってあらかじめ多少で もコイルばねをへたらせて, その後使用中の疲労変形 を少なくするという実用的意義は認められるが，セッ チングの工程がブルーイングしたばねの材質を変え, 疲労变形防止上本質的な役割をはたしているとは解釈 しにくいように思われる.

Fig. 8 からわかるように，本実験に用いたコイルば ねでは処理のいかんにかかわらず, 疲労变形限度線が 横軸と $45^{\circ}$ をなす直線に対して上方に凸な弓形になっ ており，この曲線の形は河本らの結果と本質的には同 一であるが,このような傾向がコイルばねの材質に無 関係なものかぞうかは種々の材質のものについて今後 充分検討する必要がある。

\section{5. 結}

コイルに巻いたままの無処理ばね，ブルーイング処 理したばね，さらにセッチング処理した 3 種のばねに ついて, 平均応力を種々変えて疲労变形の測定を行な い次の結果を得た.

（1）疲労変形に及活すコイル巻き後の経年変形の 影響は無視することができるが，弾去余効果の影響は 無処理ばねについては必ずしも無視することができな いから, 疲労変形の測定を除荷後なるへく短時間内に 終るようにする必要がある。

（2）無処理ばねの疲労変形限度はきわめて低いが， これにブルーイング処理を施すと著しく上昇し, 瘦労 変形の防止に対するブルーイングの効果が著しく大き いことがわかった。ブルーイングによるこのような疲 労変形限度の增大は時效硬化によるものと考えられる。 （3）本実験に用いたコイルばねでは疲労变形限度

\footnotetext{
*ブルーイング，セッチングともに工業的に行なわれたすので，七ッ チングによる変形を直接求めることができなかったので, 各10個の 自由長の平均值差として求めた
} 
線図は横軸(平均応力軸)に $45^{\circ}$ をなす直線に対して上 方に凸な弓形になり， $\tau_{m}=(0.25 \sim 0.33) \tau_{a}$ 程度の平 均応力を与えて使用する場合のほうが静荷量を負荷す る場合よりもむしろ疲労变形が起こりにくいことがわ かった。

本実験の一部は昭和 36 年度文部省研究費の援助に よるものであることを们記して謝意を表する。また， コイルばねに関し便宜を与えられた三興線材工業株式 会社小村微一，野入省吾両氏ならびに本実験に熱心に
協力された本学卒業生金井宏員, 谷川卓己両工学士に 感謝する。

\section{参考 文 献}
1) 河本, 桜井, 藤谷, 材料試験, 3, 17, 443 (1954)
2) " " " $8,75,903$ (1959)
3) 河本, 桜井, 関, 藤谷, 材料試験, 10, 89, 81 (1951)
4) 河本, 桜井, 藤谷, 材料試験, 10, 99, 977 (1961)
5) 関口, 稲垣, 日本金属学会誌, 19, 24, 28, 220, 286, 494 (1955)
6) 岡田, 渡辺, " 22, 440 (1958)

(234頁より)

アイソタクチックポリスチロールの球晶および結晶 発達に関する動力学 (Kinetics of Spherulite and Crystallite Growth in Isotactic Polystyrene) by A.S. Kenyon, R.C. Gross and A.L. Wurstner, J. Poly. Sci. Vol. 40, No. 136, p. 159 168 (Oct. 1959) 図 8 , 表 1

アイソタクチックポリスチロールの球晶と球晶の発 達速度がおのおの温度について偏光顕微鏡, X線, 密 度変化測定等の手段により研究された。実験された 2 種類のポリスチロールはNatta博士の触媒を用いて合 成された分子量 1380000 および 190000 ときわめて異 なるものである. 結晶化に伴う密度の增加はアイソタ クチックポリスチロールで結晶化度ときわめて正しい 比例関係が認められている。分子量およびアイソタク チックの度合の球晶発達速度に及俅す影響が明らかに され，とくに後者のアイソタクチックの度合は決定的 影響を与えることがわかった。球晶の発達速度の極大

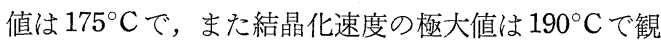
察された。このようなZiegler 型の不均值解媒を用い て合成されたポリスチロールはアイソタクチック部分 とアタクチック部分の不均質ブロックポリマーであっ て，両者のポリブレンドではないことが証せられてい る.

(伊藤勝彦)

\section{真空状態で材料を供給する押出し成型（Vacuum} Feed Extrusion) by W.M. Murdy, The Soc. of Plastics Engineers, Journal, Vol. 15, No. 10, p. $887 \sim 888$ (Oct. 1959) 図 4

大気中におけるホッパーによる普通の材料の供給に よる押し出しでは気泡の問題, 顔料や充てん剤の分散 不充分な問题が残る.これに対して材料の予熱や押し 出しスクリマーに排気路を設ける方法があるが, 真空 状態で材料を供給できるように押出材を次のように改 造すれば安価に解決できる。(1)気密ホッパーを取り 付ける。(2)押し出しリンダーバレルとスクリュ一軸 受けの間を気密にする。（3)所要の溶圧度を保てるよ うに真空ポンプをそなえる。このようにした利点は材 料中の空気や水分，発生ガスが除去されて製造に㧍け る気泡や，空隙の生じないこと。顔料や充てん剤の分
散が良好となり，材料の見かけの密度の增加にもよっ て押し出し速度が向上できること. 発泡を伴う押し成 型では真空度の調節によって気泡の大きさや均一性を かげんできる。この真空押出し法は熱可塑性樹脂の㹬 とんどに応用できるが, 塩化ビニル等に関する若干の 押し出し例が示されている。 また, 押し出し中におけ る材料の酸化の防止や，製品の多少の波打ち防止にも 有效である。

(伊藤勝彦)

ポリプロピレンの成型加工能 (Moldability of Polyropylene) by W.E. Hewmann, SPE. Journal, Vol. 16, No. 5, p. 513〜515 (May 1960) 図 7 , 表なし ポリプロピレンの射出成型を中心とした成型流れ加 工能がポリエチレン等と比較された。成型能は青銅， template によりポリマーのスパイラル状射出流れ長 さを測定して比較された。すなうち，チオンス堅型 De Mattra 射出プレスで直径 $0 \cdot 125$ 寸, 全長 50 寸の スパイラル溝ヘの流れが型温度, 射出圧力, 射出円筒 温度, ゲートの大きさ等をいろいろにしてスパイラル 射出長さに及仿す影響を中心として調へられている。 この場合, 成型サイクル 40 秒, ラム進行速度 $0.25 \mathrm{bt}$ $/ \mathrm{nün}$, 射出ラム停止時間 25 秒, 射出量, ペレット押 入量等も一定にして実験された。いろいろの Melt Index を有するポリプロピレンについで型温度 $190^{\circ} \mathrm{C}$, $250^{\circ} \mathrm{C}$ いずれの場合もスパイラル流れ長さは Melt Index にひずみ比例して増加する。型と射出円筒温度 をいろいろに組み合わせた場合の射出圧力の影響は射 出圧力の小さい間はスパイラル長さは直線的に増加す るが，射出圧力が大さくなるとスパイラル長さの增加 率は小さくなる。ゲートの大きさの影響は 0 . 125 寸と 0.080 寸について実験されているが，もちろんゲート の大きい活うが流れは良好となっている。射出円筒温 度の增大とともにスパイラル流れ長さは增加すること がポリプロピレンとポリェチレンの両者について実験 されているが，このような方法ではポリプロピレンの 射出圧型に及ぼすいろいろの因子の影響を調へてて, 実 際の射出成型の最適条件を見いだすことができること が結論されている.

(伊藤勝彦) (249 頁へ) 